\title{
Ativismo em rede e conexões identitárias: novas perspectivas para os movimentos sociais
}

\section{JORGE ALBERTO S. MACHADO*}

Introdução

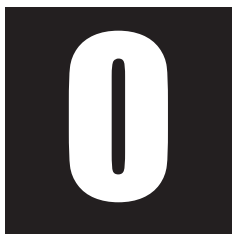

estudo e a análise do comportamento dos movimentos sociais ocupam uma posição central nas ciências sociais. No entanto, sua complexidade e diversidade fazem deste um tema muito difícil de ser abordado, assim como o de construir teorias que respondam satisfatoriamente às suas problemáticas.

Nesse texto, tento identificar quais são as características principais das novas formas de organização dos movimentos sociais, considerando a crescente incorporação das novas tecnologias de informação e comunicação em suas estratégias de planejamento, articulação e ação. Darei especial enfoque às organizações sociais mais "jovens", surgidas desde o final dos anos oitenta, ligadas a uma geração de ativistas conectados à Internet.

Defendo aqui que tais tecnologias não apenas se tornaram instrumentos de fundamental importância para a organização e articulação de tais coletivos sociais, como também proporcionaram a formação de novos mo-

\footnotetext{
* Professor Doutor da Escola de Artes, Ciências e Humanidades da Universidade de São Paulo. Brasil
} 
vimentos sociais e novas formas de ativismo. Estas passam a se caracterizar com base em uma atuação cada vez mais em forma de rede, pela formação de amplas coalizões e pelo enlaçamento ou agregação de grupos identitários, freqüentemente segundo a geografia das comunidades culturais, lingüísticas ou a identificação e compartilhamento de certos valores. A partir da análise de alguns exemplos, pretendo identificar a emergência de uma nova "cultura" organizacional nos movimentos sociais como resultado da apropriação estratégica das tecnologias de informação, apontando para novas tendências nas formas de ação coletiva.

Na primeira parte deste trabalho, são elencados alguns dos conceitos e interpretações sobre a ação e características dos movimentos sociais contemporâneos. A seguir, são exemplificadas as novas formas de atuação dos movimentos sociais em rede. Por fim, busco demonstrar as características emergentes dessas novas práticas dos movimentos sociais, com a incorporação das novas tecnologias de informação e comunicação.

\section{Movimentos Sociais: conceitos e interpretações}

Há uma grande variedade de teorias que buscam explicações para o comportamento dos coletivos sociais. A complexidade do tema e a diversidade de objetos e contextos, fazem dele uma fonte quase inesgotável de estudos, análises e novas teorizações. Ainda que muitos dos estudos possam dar respostas satisfatórias a situações que dizem respeito a contextos sociais específicos, uma breve análise da literatura sobre o tema mostra como há grande pluralidade de abordagens e interpretações.

Ao resgatar as abordagens clássicas sobre a ação coletiva, Pasquino (1992), ressalta que estas poderiam ser divididas em duas grandes correntes. De um lado, estariam as descrições que vêem uma manifestação de irracionalidade nas motivações das erupções das massas. Tais abordagens 
associam os comportamentos coletivos de massa ao questionamento ao risco à ordem social existente. Aproximam-se de tal interpretação as leituras de Le Bon, Ortega y Gasset e Tarde. Le Bon e Tarde que contrapõem os indivíduos, como agentes da racionalidade, civilização e cultura, à credulidade das massas caracterizada pela exasperação das emoções, ao instinto de manada e à tendência à imitação do comportamento coletivo (Le Bon, 2005 [1895]; Tarde, 2004 [1895]). Para Ortega y Gasset, as massas, incapazes de serem responsabilizadas em coletivo, são suscetíveis à manipulação de seus líderes. Disso resulta a irrupção de massas privadas de identidade (cf. Menucci, 1999: 13). De outro lado, estariam Marx, Durkheim e Weber que, embora com enfoques bastante distintos entre si, vêem nos coletivos sociais um modo peculiar de ação social, os quais dariam veredas a tipos de solidariedades complexas (Durkheim), a mudanças sociais do tradicionalismo para o tipo racional-legal (Weber) ou poderiam marcar o início de um processo revolucionário (Marx). Vale dizer que os autores clássicos, em sua maioria, falam em "comportamento coletivo" e "ação social". A referência deles aos movimentos sociais, ainda que de grande importância, é apenas indireta. A idéia de "movimentos sociais", tal como a concebemos hoje, não consistia, por si, em tema específico de investigação.

Uma interpretação que exerceu grande influência sobre os sociólogos foi a de Smelser (1989) [1963]. Para ele, os comportamentos coletivos se manifestam quando há condições de tensão, antes que os meios sociais tenham sido mobilizados para atuar de forma específica ou eficaz junto às causas de tal tensão. Tais comportamentos poderiam ser definidos como não-institucionalizados. Isso pode ser observado em situações em que a ação social estruturada está sob tensão, mas os meios institucionalizados para o domínio dessa tensão são inadequados. Alguns fatores como a predisposição de um sistema social a ser permeado por comportamentos coletivos, a tensão estrutural existente, os mecanismos de mobilização dos par- 
ticipantes e o controle social, seriam muito importantes para a ocorrência de movimentos sociais. A interpretação de Smelser busca responder satisfatoriamente à natureza da ação coletiva em face de sistemas sociais e políticos que se transformam com muito menos dinamismo que suas sociedades. Contudo, tal enfoque, identificado com velhos e contestados pressupostos funcionalistas, pecou por não considerar os contextos históricos específicos em que se dá a ação social.

Cabe citar outras teorias e correntes consideradas clássicas como as da escola de Chicago e os interacionistas simbólicos, principalmente Blumer (1939 e 1957) influenciado pelas obras de George Mead e Robert Park; os teóricos da sociedade de massas como Eric Fromm (1941), Hoffer (1953) e Kornhauser (1959 e 1968); os teóricos mais centrados no poder político e nas relações sociais de classe e produção como Lipset (1950) e Heberle (1951), nas correntes que combinavam elementos do interacionismo simbólico com a teoria da ação social de Parsons (1939), cujos principais expoentes foram Smelser (1962), Goffman (1959 e 1967) e Heberle (1951). Vale destacar também as contribuições da sociologia alemã, com especial influência na Europa, destacando as obras Die Masse und Ihre Aktion, de Geiger (1926) e Partei und Klasse im Lebensprozess, de Thurnwald (1926).

As abordagens consideradas "clássicas" predominaram até os anos 60 do século XX. Até então, a maioria das diferentes correntes analíticas associava a ação dos movimentos sociais a processos mais amplos e a transformações sociais, ligados às rápidas mudanças da sociedade industrial. A concepção de que o sistema político democrático capitalista era aberto, fazia com que a ação coletiva extra-institucional fosse interpretada como antidemocrática e desestabilizadora (Gohn, 2004: 25). Associava-se esse tipo de ação a anomia social e a tensões estruturais existentes. Tais abordagens eram ainda permeadas por uma forte desconfiança ideológica.

Nos dias de hoje, ainda são muitas as dificuldades para entender a natureza da ação social dos movimentos sociais. Não por acaso, Tarrow 
afirmou que o campo dos movimentos sociais é um dos mais indefiníveis que existem (cf. Melucci, 1999: 12). Visão também compartilhada por Castells, que, em meio à controvérsia que cerca o conceito, opta simplesmente por definir movimentos sociais como ações coletivas que, dependendo de seu êxito ou fracasso, "transformam valores e instituições" (Castells, 2001: 20). Para Melucci, ao tentar definir os movimentos sociais, a maioria dos autores faz pouco mais que isolar aspectos empíricos de fenômenos coletivos, acentuando elementos diferentes entre si, o que complica qualquer tipo de comparação. Segundo esse autor, o conceito de movimento social "será sempre objeto do conhecimento construído pelo analista", pois "não coincide com a complexidade empírica da ação" (Melucci, 1996: 21-2).

Se tivermos que optar por uma definição do termo 'movimentos sociais', considerando as tão variadas abordagens existentes e aceitas, poderíamos dizer que o mesmo se refere a formas de organização e articulação baseadas em um conjunto de interesses e valores comuns, com o objetivo de definir e orientar as formas de atuação social. Tais formas de ação coletiva têm como objetivo, a partir de processos freqüentemente não-institucionais de pressão, mudar a ordem social existente, ou parte dela, e influenciar os resultados de processos sociais e políticos que envolvem valores ou comportamentos sociais ou, em última instancia, decisões institucionais de governos e organismos referentes à definição de políticas públicas.

\subsection{Mudanças na Concepção de Movimentos Sociais}

A concepção de movimentos sociais esteve, durante boa parte do tempo, associada aos movimentos de caráter revolucionário cujas ações e lutas políticas se enquadravam dentro de um espectro político freqüentemente mais radical. Até os anos 70, era freqüente a associação das lutas políticas dos movimentos sociais a um suposto quadro de luta de 
classes no interior das sociedades capitalistas - portanto, dentro de um contexto muito mais amplo, relacionado com o desenvolvimento das forças produtivas e das relações de produção existentes. Os movimentos sociais eram identificados basicamente como um produto da ação histórica da sociedade, ante as contradições do sistema capitalista.

Tal interpretação da natureza dos movimentos sociais foi particularmente característica nas abordagens marxistas-estruturalistas. Esta leitura se foi tornando antiquada à medida que os movimentos sociais passaram a proliferar, ganhando notável complexidade e alcance com o surgimento de organizações e coletivos que lutavam pelas causas mais diversas. Surgiu então o termo "novos movimentos sociais" para designar tais coletivos que não encontravam uma interpretação satisfatória na maioria das interpretações predominantes. Os "novos" movimentos sociais seriam principalmente os movimentos pacifistas, das mulheres, ambientalistas, contra a proliferação nuclear, pelos direitos civis e outros. Tais movimentos, a maioria de base urbana, estavam bastante afastados do caráter classista dos movimentos sindical e camponês, atuando, não raras vezes, em cooperação com o sistema econômico e no escopo político das instituições vigentes.

A diversificação dos movimentos sociais ocorreu em um processo intimamente ligado ao aprofundamento dos mecanismos e instituições democráticas nas sociedades ocidentais capitalistas. Só não existiam movimentos sociais nas sociedades "sem classes" socialistas, devido à própria repressão que o regime exercia sobre qualquer movimento reivindicativo cuja origem estivesse fora do espaço de controle do governo ou do partido. Tais regimes impediam que as tensões sociais pudessem vir a manifesto através de canais ou "escapes" espontâneos da sociedade civil, que não fossem os meios oficiais permitidos. Nesse contexto, o "movimento social" estava, em tese, incorporado às estruturas do governo, já que ele deveria confundir-se com o próprio processo revolucionário, expressão última da vontade das massas e base do governo "proletário". 
Com o processo de abertura política após a crise do bloco soviético, viu-se que organizações civis de todo tipo subsistiam sob o cimento do socialismo, alguns atores sociais puderam aos poucos organizar-se em torno de suas identidades, graças às novas liberdades conquistadas. O "súbito" surgimento de mais de mil organizações sociais, agremiações políticas e outros coletivos civis na ex-União Soviética, no início do processo de democratização, é uma prova contundente disso. Isso evidenciou que, ainda que pudessem ser uma expressão de luta de classes ou da desigualdade social, os movimentos sociais nunca dependeram disso para existir. Ao contrário, seu fortalecimento e proliferação estiveram mais associados ao amadurecimento ou transformação das instituições democráticas e da própria capacidade de organização da sociedade civil.

Observa-se hoje que as demandas dos movimentos sociais são tão variadas, específicas e, inclusive, peculiares a certos contextos sociais, históricos e culturais. O erro da abordagem marxista da ação social foi a aceitação quase dogmática de um tipo de interpretação baseada nas estruturas sociais de classes e seus antagonismos e tratar pouco da questão das identidades, valores e da importância dos mecanismos e dinâmicas do sistema político.

\subsection{Da lógica do conflito à cooperação}

A mudança no entendimento da organização e ação dos coletivos sociais ocorreu, em grande parte, em decorrência das transformações no cenário político internacional. Com o fim da guerra fria e o surgimento da simbiose entre democracia ocidental e capitalismo, os movimentos sociais passaram gradualmente a ser considerados atores sociais importantes para a promoção dos direitos civis e da cidadania. Com a dissipação das brumas do conflito ideológico, as iniciativas da sociedade civil incorporadas na ação dos movimentos sociais, mesmo que originadas "fora" do escopo político 
do Estado - e de seus mecanismos controles - ao invés de serem vistas como subversivas, revolucionárias ou marginais, passaram a ser entendidas como manifestações próprias, típicas e até mesmo sadias de um ambiente político e social plural. Gradualmente o Estado passou a vê-los como parceiros estratégicos e necessários que, ao mesmo tempo em que aumentavam o alcance das democracias, emprestavam legitimidade e até prestigio aos governos.

A incorporação desses atores sociais à esfera política foi exitosa ao inverter a lógica do conflito para a da cooperação, proporcionando, assim, um maior alcance das instituições civis no âmbito de uma governança democrática. Os movimentos sociais conseguiram mais legitimidade em suas ações reivindicatórias quando o governo e suas instituições assumiram práticas políticas cooperativas, fomentando instrumentos e políticas públicas que proporcionassem maior "porosidade" às demandas dos coletivos sociais. A mudança culminou com o reconhecimento, por parte das legislações nacionais, do status jurídico e político de tais formações sociais. Então, o Estado passou a incorporar, através de arranjos institucionais e políticos, a ação social de organizações originadas na sociedade civil, como é o notório no caso das organizações não-governamentais.

Embora os movimentos sociais não possam ser confundidos, a rigor, com organizações sociais tais como as ONGs, de fato as distinções são freqüentemente difíceis de serem feitas. Muitos movimentos sociais, ao se desenvolverem, acabam por adquirir um caráter mais institucional como representantes legítimos ou mediadores de certas demandas e interesses de um segmento específico da sociedade. Por tal razão, muitos autores se referem a sindicatos, organizações religiosas, ligas urbanas, movimentos de bairro, microagremiações políticas, associações de camponeses, coletivos feministas e outros, igualmente como "movimentos sociais". Possivelmente o caráter comum que eles têm é que suas bases estão na sociedade civil e, por outro lado, são portadores de uma legitimidade freqüentemente nãoinstitucional. 


\section{3 Movimentos Sociais e Democracia}

Em virtude das mudanças no contexto político, os movimentos sociais passaram a desempenhar importantes papéis como catalisadores de demandas sociais não contempladas pelo Estado - seja através das políticas públicas, seja através da falta de reconhecimento de tais atores sociais como atores políticos.

À medida que os Estados passaram a reconhecer a legitimidade dos movimentos sociais como atores políticos, observou-se - pelo menos nos países ocidentais - um notável crescimento de parcerias e iniciativas comuns entre os mesmos. Com base em tais experiências, foram criadas (primeiro na Europa, depois na América), políticas de fomento para apoiar a ação participativa dos coletivos sociais e novas formas de parceria com governos.

Sobre esse processo de mudança, vale destacar certos aspectos fundamentais:

a) A incorporação dos movimentos sociais como parceiros do governo democrático tem contribuindo para uma crescente institucionalização dos mesmos dentro dos sistemas políticos. Ainda que admitamos que este não é o caso da maioria, os movimentos sociais já entraram em uma fase em que não podem ser mais definidos genericamente como "não-institucionais", conforme destacam alguns autores (Melucci, 1999; Pasquino, 1994: 791).

b) Ao contrário do que afirmam alguns autores (como Alexander, 1998), nem todo movimento social se insere numa luta por uma melhor distribuição das recompensas e sanções ou tem exatamente um "adversário" - como afirmam Castells (2001) e Touraine (1995). Diferentemente de outros tempos, muitos movimentos sociais visam a cooperação, o voluntariado ou a preservação cultural. Não deve haver necessariamente um problema distributivo ou alguma contestação, para sua existência. 
As motivações podem ser as mais diversas, tais como uma crença religiosa, um ideal, uma identificação com um grupo ou interesse específico em um certo contexto. Ainda que admitamos que a distribuição de recursos - sejam recursos financeiros, prestígio ou poder - ou a existência de um "adversário" possa estar direta ou indiretamente relacionada com suas motivações, este já não é um elemento definitivo nos processos de formação de tais coletivos sociais. Há outros aspectos, de caracteres identitários, vinculados ao crescente multiculturalismo das sociedades contemporâneas e ao incremento da possibilidade de agenciamentos do indivíduo em relação ao amplo arco de interesses, relacionamentos e visões do mundo às quais é confrontado - que assumem importância cada vez maior como liame do sujeito com os coletivos sociais.

c) As mudanças históricas e as adaptações estratégicas nas formas de organização e atuação dos movimentos sociais obraram para que os mesmos pudessem reivindicar sempre que necessário, como forma de se autolegitimarem, os pressupostos do Estado democrático e as liberdades constitucionais de organização e expressão ideológica e política. Tal processo culminou com a organização e a associação dos indivíduos, as quais passaram não apenas a ser garantidas, como incentivadas pelos sistemas democráticos - inclusive em vias do fortalecimento dos governos eleitos, considerando o cenário de erosão do Estado. ${ }^{1}$

Alan Touraine, desde que se afastou das abordagens marxistas ortodoxas, tem enfatizado a importância da democracia para os movimentos sociais, assim como destes para a democracia:

1 É evidente também que a falta de dinamismo e eficiência do Estado, assim como os processos de erosão de sua autoridade facilitaram a emergência das organizações não-governamentais. No entanto, não caberia neste pequeno texto tratar de assunto tão complexo, que merece maior atenção. Uma abordagem mais detalhada sobre o tema pode ser encontrada em Held (1997). 
Mais do que a criação de uma sociedade política justa ou a abolição de todas as formas de dominação e exploração, o principal objetivo da democracia deve ser permitir que indivíduos, grupos e coletividades se tornem sujeitos livres, produtores de sua história, capazes de reunir em sua ação o universalismo da razão e as particularidades da identidade pessoal e coletiva. (Touraine, 1995: 263)

Para esse autor, a história da liberdade no mundo moderno "é a de uma associação cada vez mais estreita entre o universalismo dos direitos humanos e a particularidade das situações e relações sociais nas quais esses direitos devem ser protegidos" (Touraine, 1995: 263). Para ele, "somente nas sociedades democráticas é que os movimentos sociais se formam sozinhos, pois a livre escolha política obriga cada ator social a lutar simultaneamente pelo bem comum e pela defesa de interesses particulares. Por essa razão, os movimentos sociais mais expressivos recorreram a temas universalistas: liberdade, igualdade, direitos do homem, justiça, solidariedade, temas que estabelecem um nexo direto entre o ator social e o programa político" (Touraine, 1995: 88).

Podemos afirmar que esta dimensão universalista vai bem mais além da temática dos direitos humanos. Relaciona-se ao compartilhamento cada vez mais amplo de valores vinculados aos direitos das minorias, à liberdade de expressão, à conservação ambiental, direito à diversidade cultural, liberdade religiosa, igualdade racial, igualdade de gênero, qualidade de vida e a uma distribuição mais justa dos benefícios sociais da economia global, etc. Trata-se também de temas que hoje são centrais nas agendas dos governos e dos organismos multilaterais. A luta coalizacional dos movimentos sociais caminha cada vez mais em paralelo com a incorporação de tais valores e aspirações às leis e às práticas políticas dos governos nacionais e locais.

É nesse contexto, que os movimentos sociais ajudam a constituir legitimamente a base de muitos dos mecanismos de pressão para o aperfeiço- 
amento das instituições democráticas. Fortalecidos pelo direito internacional que vincula cada vez mais legitimidade à democracia (ver Held, 1997: 131-138), a legitimidade de ação dos movimentos sociais se baseia sempre mais em certos princípios "universais", mesmo para defender o particularismo de sua causa e reivindicar o "direito à diferença" das minorias.

Com sua "institucionalização" como ator social necessário para o aperfeiçoamento da democracia, vimos que os movimentos sociais passaram a ser, provavelmente, os mais dinâmicos catalisadores das tensões e conflitos sociais. Portanto, na travessia dos anos noventa e no início do século XXI, os movimentos sociais adquiriram um papel-chave como ator político em um Estado democrático, pela importância reconhecida como portador legítimo e representante dinâmico de reivindicações de diferentes setores da sociedade civil.

Nos tópicos a seguir, coloco em relevo as transformações da ação coletiva em vistas da apropriação e de inovadores usos dados aos novos e potentes instrumentos relacionados às modernas tecnologias de informação e comunicação. Seguindo a tendência de outros segmentos da sociedade e da própria Economia, sustento que o novo passo fundamental na história dos movimentos sociais é para seu novo tipo de organização, reticular, com ações que envolvem articulação e alcance cada vez mais globais. Esta seria a forma mais eficiente para se contrapor à ação de organizações e corporações com poderes cada vez mais globais - fora do controle democrático dos governos locais - em um ambiente marcado por instituições locais cada vez mais solapadas pela ação desestabilizadora de tais atores.

\section{Movimentos sociais e (des)governança global: novos campos de batalhas para velhos conflitos}

Nas últimas duas décadas, houve uma grande mudança nas concepções de democracia, predominantemente aceitas no Ocidente. Os docu- 
mentos internacionais que respaldam os direitos humanos, das mulheres, de crianças e das minorias, são expressões de certos consensos. Organismos internacionais zelam de alguma forma pelo cumprimento de tratados e acordos internacionais. Isto, sem dúvida, tem refletido sobre a forma como o governo e as instituições estatais tratam tais temas, especialmente pela possibilidade de ocorrência de sanções e reprimendas internacionais.

No entanto, apesar desta mudança formal da relação entre os governos e a sociedade civil com respeito a como tratar tais direitos civis e sociais, as relações entre movimentos sociais e instituições, governos e até mesmo destes com as corporações, estão permeadas de conflitos. A crescente cooperação entre sociedade civil e instituições governamentais no marco do Estado democrático - em que um dos pilares é a crescente atuação dos movimentos sociais organizados -, não impediu que esta lógica fosse desafiada, tanto no campo político quanto no social, por outros elementos de descontrole. Trata-se de fontes de conflito que surgiram, em grande parte, em decorrência da crescente interdependência entre os atores, da emergência de novas identidades "globais", da natureza cada vez mais ambígua e polivalente das fronteiras culturais e - o que pretendemos explorar aqui - das novas formas de articulação e organização que se apóiam nas modernas tecnologias de informação.

Portanto, antes de seguir adiante, vale explorar tais elementos. Conceitualmente opta-se aqui por fazê-lo a partir de três fatores fundamentais: a interdependência entre os atores políticos e sociais, o descontrole e o empoderamento dos agentes sociais e econômicos. Eles estão ligados a:

1) Interdependência e interconexão reativa. Há uma situação cada vez mais difusa e indefinida no que se refere à relação do governo local com o "governo global". As decisões de governos locais não afetam apenas o Estado ou a jurisdição a que se refere; desafortunadamente, estes também têm que responder a situações que estão fora de seu "espaço" de controle. 
As tentativas de "reordenar" ou buscar novas condições de equilíbrio passam inexoravelmente, pelo consertamento político entre os atores envolvidos. Tratados, acordos e pactos internacionais passam a ser cada vez mais necessários. Dessa forma, governos, empresas, coletivos sociais e organizações diversas devem buscar respostas à altura para tais situações, o que significa articular ações cada vez mais complexas, envolvendo cooperação, parcerias e alianças com outros atores sociais que atuam a partir de âmbitos externos.

Se a crescente interdependência entre o global e o local faz com que as decisões que afetam as comunidades políticas "fujam" das instâncias de controle local, a interconexão reativa dos atores locais contribui de alguma forma para solapar as instituições democráticas locais. Isso ocorre, pois, no intento de obter controle, estabelecem-se novas conexões.

2) Zonas cinzas de descontrole. No que se refere a corporações econômicas, principalmente as de grande porte, estas estão cada vez mais freqüentemente fora do controle dos governos democraticamente eleitos. Isto significa também que elas atuam dentro de contextos jurídicos variáveis ou até "inexistentes", em uma zona "cinza" onde é possível resguardar-se, ou escapar das jurisdições locais e dos controles das sociedades civis organizadas no interior dos Estados. Referimo-nos, por exemplo, à movimentação de capital (alocação de investimento, remessas internacionais, transações entre filiais), ao uso da mão-de-obra, ao respeito às leis ambientais e ao respeito aos direitos sociais e trabalhistas, entre outros aspectos.

O mundo das grandes corporações impõe grandes desafios às democracias, assim como à atuação dos movimentos sociais. Em contexto de conflitos, isto acaba resultando no surgimento de práticas e reações bem diversas de ambas as partes e até à sombra do Estado. ${ }^{2}$

2 Nesse contexto estão o hacktivismo e o ciberterrorismo. Cada vez mais freqüentes, eles atuam nessas "áreas cinzas" onde é difícil estabelecer jurisdições e responsabilidades (Machado, 2003) 
3) O empoderamento das agências sociais. A sociedade da informação dispõe de ferramentas que acirram a competição entre as agências sociais. As oportunidades e riscos nos negócios cada vez mais complexos e arrojados bem como a instabilidade dos mercados nacionais integrados em um gigante mercado global, impõem crescentes desafios à intervenção e controle dos Estados nacionais, prejudicando a governabilidade e o accountability. Se, por um lado, como observa Held (1997), uma grande parte das decisões que afetam a vida das pessoas são tomadas em espaços juridicamente não definidos, nos quais a opinião pública e as maiorias nacionais têm uma influência mínima, por outro lado, este mesmo cenário tem possibilitado níveis de organização, intercâmbio e ação cada vez mais complexos por parte de indivíduos, grupos e organizações sociais - impossíveis de serem levados a cabo há alguns anos atrás. Atualmente, ferramentas tecnológicas potencializam enormemente a ação de um mero punhado de indivíduos. Tal cenário aponta para conflitos de difícil mediação, marcados pela ação e organização virtual, eletrônica, cada vez mais desterritorializadas, desencadeada pelos mais diversos atores sociais - muitas vezes insuspeitos. Em um espaço onde não há, de fato, um governo, uma autoridade legítima, fica difícil a distinção entre as formas de ativismo mais pacíficas daquelas mais incisivas, que beiram a ações criminosas de grandes proporções. Este recente "empoderamento" das agências sociais e individuais ainda é elemento pouco estudado e analisado nas ciências sociais.

Assim como os atores políticos e econômicos se globalizam, o mesmo fazem os coletivos sociais, de forma a compensar a desigual distribuição de recursos e poder, ao incorporarem o que as novas tecnologias de informação e comunicação melhor Ihes oferecem.

Devido ao aumento da ação coletiva em áreas de difícil definição jurídica e política, ativismo político, crime e engajamento em causas sociais se confundem cada vez mais na ação dos movimentos, por uma globalização 
alternativa dos grupos radicais e das diversas organizações que atuam em redes supranacionais.

Novas formas de atuação

A guerra de informação durante a invasão do Iraque foi um exemplo emblemático das novas formas de atuação. Enquanto a grande mass media estadunidense e mundial se inclinava para uma "leitura" claramente próEUA, agências menores de noticias, media árabe, bloggers, coletivos sociais antiguerra, ativistas diversos e a imprensa independente davam outras versões do conflito. Esse eclético "mass media alternativo" difundia notícias e imagens que normalmente não chegavam aos telespectadores pelas emissoras de TV e grandes agências internacionais. Seus conteúdos proliferavam rapidamente pela rede, alcançando milhões de pessoas conectadas, ávidas por informações do conflito. Ademais, havia uma grande difusão de e-mails, mensagens SMS, comunicações por telefonia móvel e transmissões ao vivo do front, via satélite. Isto desencadeou uma verdadeira guerra de informação para conquistar corações e mentes.

Neste mesmo contexto, uma organização surgida unicamente com base na rede, a MoveOn.org, conseguiu a proeza de organizar o maior protesto já realizado nas ruas de Nova lorque, levando 250 mil pessoas às ruas para se manifestarem contra a guerra, no dia 15 de fevereiro de 2003. Além de difusão de mensagens, o MoveOn levantou recursos, através de seu site, para estender sua campanha publicitária para emissoras de TVs, periódicos e rádios.

Um outro exemplo recente foi a reação popular à posição do governo espanhol depois do atentado de 11 de março de 2003, em Madrid. Às vésperas da eleição, as autoridades espanholas tentaram a todo custo responsabilizar o grupo separatista basco ETA pelos atentados, retendo infor- 
mações e pressionando fortemente os grandes veículos de comunicação nacional. Isso porque havia enviado tropas de apoio à invasão do Iraque, contrariando a imensa maioria da população, que não queria ver o país envolvido no conflito e muito menos ainda, incluído no mapa do terrorismo islâmico. Nas horas seguintes às explosões, à medida que as informações advindas dos organismos de segurança se mostravam contraditórias e suspeitas, observou-se uma grande reação em cadeia. Milhões de mensagens SMS foram deflagradas para protestar contra a ação do governo. Fora dos canais tradicionais, blogs, fotos enviadas em tempo real das manifestações e e-mails denunciavam a farsa pré-eleitoral. Mesmo contando com uma imprensa "cautelosa", submetida a pesadas pressões vindas até do gabinete presidencial, o partido do governo, antes franco favorito nas eleições, viu, em questão de horas, seus planos de permanência no poder ruírem. Isso não seria possível se não fosse a utilização das ferramentas tecnológicas como apoio à ação cidadã.

Tradicionalmente muitos governos e corporações conseguiam impor medidas contra os interesses coletivos, devido à crença na incapacidade de organização e resistência dos afetados. Contudo, com o uso criativo das tecnologias de informação e comunicação, ações específicas e circunstanciadas podem gerar um agregado de peso de forças contrárias de alcance global. Aos indivíduos e coletivos sociais, que outrora se encontravam dispersos ou isolados, é possível concentrar suas ações em prol de uma causa comum, com base nas extensas redes de solidariedade de natureza identitária.

Exemplos não faltam: ecologistas locais e suas redes de denuncia e articulação global, ativistas dos direitos humanos e as grandes organizações internacionais (Anistia Internacional; American Watch), grupos por uma globalização alternativa e as redes de organizações em apoio aos países pobres e aos excluídos dos benefícios da economia global, redes de exila- 
dos palestinos pelo mundo (como a Palestinian NGOs Network). Se não bastasse, observam-se alianças e trocas de informações e apoio entre as diferentes redes de coletivos sociais, explorando seus elementos comuns. Falamos, portanto, de redes, hoje, que incluem centenas de entidades, que trocam informação, formam grupos de pressão e se apóiam mutuamente. Essas redes são incomparavelmente maiores que há pouco mais de dez anos atrás, quando se começou a falar delas.

\subsection{Organizando-se em rede: alguns casos}

Alguns exemplos de atuação em rede por parte das organizações sociais são os da Third World Network, Oxfam Intenacional, No Border, Palestinian NGOs Network, Global Trade Watch, Indymedia, Nodo50 e IGC/APC. Nos casos da Indymedia e do Nodo50, trata-se de agências de informação alternativa e contra-informação.

Optou-se por listar principalmente as redes de organizações, espécies de pontos nodais de coletivos e agrupações de ativistas menores e diversas. Poderiam ser nomeadas ainda outras redes de organizações de bastante relevo como a SETEM, a Confédération Paysanne, ATACC, entre outras. No entanto, suas características e formas de articulação não se diferenciam muito das acima referidas. Vale citar também o Fórum Social Mundial, uma organização que desempenha importante papel como espaço de articulação e debate entre as diferentes redes de movimentos sociais.

Há ainda organizações que embora não atuem em rede de organizações, reúnem redes com centenas de milhares de pessoas, com um grande poder de mobilização e lobby. É o caso da Public Citizen, nos EUA, organização de defesa do cidadão e consumidor, que milita por causas tão diversas como justiça econômica e social nos negócios comerciais, accountability político, uso de energias limpas e sustentáveis, proteção ambiental e saúde.

Mesmo organizações mais antigas, "pré-Internet", como Greenpeace, WWF, American Watch ou Anistia Internacional utilizam a rede para divul- 
Sociologias, Porto Alegre, ano 9, no 18, jul./dez. 2007, p. 248-285

\begin{tabular}{|c|c|c|c|}
\hline Organização & Objetivo & Historico & Formas de atuação \\
\hline $\begin{array}{c}\text { Oxfam } \\
\text { Internacional }\end{array}$ & $\begin{array}{l}\text { Tem como objetivo en- } \\
\text { contrar soluções para a } \\
\text { pobreza e as condições } \\
\text { de injustiça. }\end{array}$ & $\begin{array}{l}\text { Uma das redes de organizações que mais ganhou relevo nos } \\
\text { últimos anos. Reúne em uma confederação } 12 \text { organizações } \\
\text { que trabalham em conjunto com cerca de } 3000 \text { organizações } \\
\text { locais no mundo todo. Para alcançar seus propósitos, a Oxfam } \\
\text { desenvolve intensos lobbys junto aos organismos internacio- } \\
\text { nais, além de promover campanhas informativas e participar } \\
\text { de programas de desenvolvimento. }\end{array}$ & $\begin{array}{l}\text { Promove campanhas informati- } \\
\text { vas, divulga documentos, articu- } \\
\text { la-se através da rede com as } 12 \\
\text { organizações que atuam com ou- } \\
\text { tras redes locais em mais de cem } \\
\text { países. }\end{array}$ \\
\hline $\begin{array}{l}\text { The Palestinian } \\
\text { NGO Network }\end{array}$ & $\begin{array}{l}\text { Coordenar a atuação das } \\
\text { organizações em apoio à } \\
\text { causa palestina espalha- } \\
\text { das pelo mundo; buscan- } \\
\text { do estratégias comuns }\end{array}$ & $\begin{array}{l}\text { Fundada em 1993, depois da assinatura do tratado de Oslo, esta } \\
\text { rede dá suporte a entidades civis que lutam pelos direitos do } \\
\text { povo palestino, atuando como "guarda-chuva" de } 92 \text { organiza- } \\
\text { ções. A PNGO colabora ainda com outras organizações ou } \\
\text { redes de organizações, como Sabeel Ecumenical Liberation } \\
\text { Theology Center, The General Union of Palestinian Women, } \\
\text { Christian Aid Christian Peacemaker Teams (CPT), Coalition of } \\
\text { Women for Peace, Ecumenical Accompaniment Program in } \\
\text { Palestine and Israel (EAPPI), International Solidarity Movement } \\
\text { (ISM), International Women's Peace Service (IWPS), Israeli } \\
\text { Committee Against House Demolitions, World Council of } \\
\text { Churches }\end{array}$ & $\begin{array}{l}\text { Através de seu site, a PNGO di- } \\
\text { vulga suas estratégias de luta, pu- } \\
\text { blicações, informação sobre cam- } \\
\text { panhas, projetos em andamento, } \\
\text { notícias, documentos e comunica- } \\
\text { dos. Sua página web se transfor- } \\
\text { mou em um veículo de referên- } \\
\text { cia, integração e intercambio en- } \\
\text { tre as organizações que formam a } \\
\text { PNGO. }\end{array}$ \\
\hline $\begin{array}{l}\text { IGC e APC } \\
\text { (Institute for } \\
\text { Global } \\
\text { Communications } \\
\text { e Association for } \\
\text { Progressive } \\
\text { Communications }\end{array}$ & $\begin{array}{l}\text { Apoiar, por meio do uso } \\
\text { das TIC, as organizações } \\
\text { de todo o mundo que atu- } \\
\text { am por direitos humanos, } \\
\text { paz, meio-ambiente, de- } \\
\text { senvolvimento sustentá- } \\
\text { vel, direitos da mulher e } \\
\text { dos trabalhadores. }\end{array}$ & $\begin{array}{l}\text { Foi fundado em } 1987 \text { para dar suporte à rede de organizações } \\
\text { pacifistas PeaceNet. Em parceria com seis organizações inter- } \\
\text { nacionais, a IGC fundou, em 1990, a APC. A APC é uma coa- } \\
\text { lizão internacional de redes de computadores de entidades } \\
\text { progressistas, com } 25 \text { membros e } 40 \text { parceiros. A APC diz } \\
\text { apoiar a um mundo onde as pessoas possam usar o "potencial } \\
\text { criativo das T.I.C. para melhorar suas vidas e criar sociedades } \\
\text { mais igualitárias e democráticas" (APC, 2005). Sua assembléia } \\
\text { consultiva é formada por membros de outras organizações ou } \\
\text { redes de organizações como Peacefire.org, GreenMarketplace, } \\
\text { Project Change Anti-Racism Initiative e redes como Envirolink } \\
\text { Network, The Women's Network. }\end{array}$ & $\begin{array}{l}\text { O IGC oferece serviço de hospe- } \\
\text { dagem na rede à cerca de } 250 \text { or- } \\
\text { ganizações sem fins lucrativos. } \\
\text { oferecer também suporte à forma- } \\
\text { ção de outras redes como a } \\
\text { EcoNet, WomensNet, LaborNet e } \\
\text { AntiRacismNet. } \\
\text { A APC oferece ferramentas de } \\
\text { comunicação e compartilha- } \\
\text { mento de informação para orga- } \\
\text { nizações não-governamentais e } \\
\text { ativistas de mais de } 130 \text { países. }\end{array}$ \\
\hline $\begin{array}{l}\text { Indymedia } \\
\text { (Centro de } \\
\text { Mídia } \\
\text { Independente- } \\
\text { CMls) }\end{array}$ & $\begin{array}{l}\text { Apoiar e promover o in- } \\
\text { tercâmbio de notícias } \\
\text { entre a imprensa indepen- } \\
\text { dente em todo o mundo }\end{array}$ & $\begin{array}{l}\text { Reúne centros alternativos de mídias do mundo todo. Foi for- } \\
\text { mada para cobrir a reunião da OMC, e m Seattle, em 1999, } \\
\text { utilizando a Internet como sua base para difundir informes, } \\
\text { vídeos, áudios e fotos registradas. } \\
\text { Após o fracasso da cúpula, a Indymedia se consolidou. Passou } \\
\text { a publicar um jornal em Seattle - e em outras cidades através } \\
\text { da rede - e fundou uma estação de rádio. No site, foi desenvol- } \\
\text { vido um inovador sistema de publicação aberta, mediante } \\
\text { cadastro. A difusão dos CMls começou depois das coberturas, } \\
\text { em 2000, dos protestos contra o FMl e Banco Mundial. Atual- } \\
\text { mente há mais de uma centena de CMls espalhados pelo mundo. }\end{array}$ & $\begin{array}{l}\text { A organização se dá basicamente } \\
\text { através da Internet, envolvendo } \\
\text { discussões internacionais entre os } \\
\text { membros do centro, inicialmente } \\
\text { através de suas listas }{ }^{1} \text { e IRC. Tam- } \\
\text { bém utilizam um sistema de } \\
\text { gerenciamento de conteúdo cha- } \\
\text { mado Twiki, }{ }^{2} \text { que funciona como } \\
\text { site de acesso aberto. Não possui } \\
\text { escritório central, nem endereço, } \\
\text { telefone e fax, ainda que alguns CMl } \\
\text { possam tê-los. }\end{array}$ \\
\hline $\begin{array}{l}\text { Global Trade } \\
\text { Watch (GTW) }\end{array}$ & $\begin{array}{l}\text { Fomentar a democracia } \\
\text { através da promoção de } \\
\text { um mercado mais justo } \\
\text { e responsável como al- } \\
\text { ternativa ao modelo } \\
\text { corporativo de comércio } \\
\text { mundial }\end{array}$ & $\begin{array}{l}\text { Um bom exemplo de organização que faz parte de outras } \\
\text { redes de organizações de alcance mundial. Os temas princi- } \\
\text { pais da GTW são proteção ambiental, saúde, justiça econômi- } \\
\text { ca, segurança, democracia e responsabilidade política (GTW, } \\
\text { 2005). A GTW faz parte do comitê executivo da Citzen Trade } \\
\text { Campaign, }{ }^{1} \text { coalizão que reúne entidades de trabalhadores, } \\
\text { ambientais, religiosas, ligas de consumidores, fazendas fami- } \\
\text { liares com o objetivo de lutar por políticas comerciais social e } \\
\text { ambientalmente justas. A GTW também faz parte da rede Our } \\
\text { World Is Not For Sale (OWINFS), que reúne organizações, } \\
\text { movimentos sociais e ativistas independentes do mundo todo } \\
\text { que lutam contra o modelo corrente da globalização incorpo- } \\
\text { rada pelas práticas do comércio internacional. }\end{array}$ & $\begin{array}{l}\text { Usa a rede para divulgar documen- } \\
\text { tos, fazer denúncias, difundir e } \\
\text { promover campanhas angariar } \\
\text { fundos, articular-se com seus } \\
\text { membros, divulgar atividades, } \\
\text { notícias, documentos e comunica- } \\
\text { dos, além de ajudar a promover e } \\
\text { apoiar organizações aliadas e suas } \\
\text { atividades. }\end{array}$ \\
\hline
\end{tabular}

1 Para ver as listas: < $<$ http://lists.indymedia.org/ $>$.

2 Ver $<$ http://docs.indymedia.org/ $>$.

3 (http://www.citzentrade.org) 
Sociologias, Porto Alegre, ano 9, no 18, jul./dez. 2007, p. 248-285

\begin{tabular}{|c|c|c|c|}
\hline Organização & Objetivo & Historico & Formas de atuação \\
\hline Nodo50.org & $\begin{array}{l}\text { Dar suporte informático } \\
\text { a movimentos e coletivos } \\
\text { sociais diversos, superar } \\
\text { a fragmentação dos mo- } \\
\text { vimentos sociais e promo- } \\
\text { ver a difusão de "contra- } \\
\text { informação". }\end{array}$ & $\begin{array}{l}\text { Reunindo } 853 \text { organizações sociais, o Nodo50 surgiu com base } \\
\text { em um simples BBS (Bulletin Board System), durante a come- } \\
\text { moração dos } 50 \text { anos do FMl e do Banco Mundial, em 1994, em } \\
\text { Madrid. Seu objetivo era dar suporte às organizações que pre- } \\
\text { tendiam denunciavam a forma de atuação de tais organis- } \\
\text { mos. }{ }^{4} \text { Em } 1996 \text {, o Nodo50 se tornou um provedor de acesso } \\
\text { com o objetivo de apoiar a campanhas as ações de movimen- } \\
\text { tos sociais e pequenas organizações políticas. As organizações } \\
\text { que fazem parte do Nodo50 são ligadas principalmente aos } \\
\text { movimentos feministas, ecologistas, sindicalistas e grupos in- } \\
\text { ternacionais de apoio, solidariedade ou cooperação ao desen- } \\
\text { volvimento. A idéia é "superar a fragmentação dos movimen- } \\
\text { tos em ilhas atomizadas, trabalhando na construção de um } \\
\text { arquipélago interconectado de resistências e ações coletivas }{ }^{\prime \prime} \\
\text { (Nodo50, 2005). }\end{array}$ & $\begin{array}{l}\text { O Nodo50, além de oferecer co- } \\
\text { nexão, espaço para hospedagem, } \\
\text { gestão de domínios e outros servi- } \\
\text { ços comuns a empresas do ramo, } \\
\text { faz projetos gráficos, dá cursos dé } \\
\text { formação, facilita a busca e a ins- } \\
\text { crição em suas organizações, } \\
\text { apóia e divulga suas campanhas, } \\
\text { facilita a difusão e o intercâmbio } \\
\text { de informações entre tais organi- } \\
\text { zações, através de sua lista pró- } \\
\text { pria e da de outras organizações } \\
\text { que difunde. }\end{array}$ \\
\hline No Border & $\begin{array}{l}\text { Coordenar a luta de } \\
\text { ONGs e movimentos so- } \\
\text { ciais contra a migração } \\
\text { global com base no recru- } \\
\text { tamento exploração e } \\
\text { econômica de trabalha- } \\
\text { dores. }\end{array}$ & $\begin{array}{l}\text { Criada em 1999, em Amsterdã, trata-se de uma rede formada } \\
\text { por mais de } 150 \text { organizações e grupos de ativistas europeus } \\
\text { em defesa dos imigrantes e contra as formas de discriminação. } \\
\text { Sua principal luta é contra as políticas de deportações de exi- } \\
\text { lados estrangeiros por parte de governos, assim como contra } \\
\text { as corporações que se beneficiam de alguma de tal situação. } \\
\text { A No Border é conhecida por suas estratégias arrojadas de } \\
\text { atuação, o que incluem hackerismo e campanhas em rede } \\
\text { contra governos e empresas. }\end{array}$ & $\begin{array}{l}\text { A coordenação entre os grupos de } \\
\text { ativistas é feita através de uma lis- } \\
\text { ta de e-mail e dois encontros } \\
\text { anuais. Promove ocupações, } \\
\text { acampamentos junto a aeropor- } \\
\text { tos, manifestações simultâneas } \\
\text { em vários países e hackerismo. }\end{array}$ \\
\hline $\begin{array}{l}\text { Third World } \\
\text { Network }\end{array}$ & $\begin{array}{l}\text { Apoio ao desenvolvimen- } \\
\text { to e à cooperação inter- } \\
\text { nacional }\end{array}$ & $\begin{array}{l}\text { Rede internacional independente de organizações e indivíduos } \\
\text { envolvidos em assuntos relacionados com o desenvolvimento } \\
\text { e as relações Norte-Sul. Concentra-se sobre a investigação } \\
\text { sobre assuntos econômicos, sociais e ambientais referentes } \\
\text { aos países em desenvolvimento; publica livros e revistas, or- } \\
\text { ganiza seminários e apresenta plataformas de apoio aos inte- } \\
\text { resses dos países do Sul junto às conferencias internacionais. A } \\
\text { TNW possui escritórios na África, América, Ásia e Europa. } \\
\text { Conta com organizações filiadas nos países em desenvolvi- } \\
\text { mento, com quem desenvolve parcerias. }\end{array}$ & $\begin{array}{l}\text { Divulga documentos, distribui in- } \\
\text { formes, promove faz campanhas } \\
\text { informativas, eventos. Coordena- } \\
\text { se com outras organizações pela } \\
\text { rede. }\end{array}$ \\
\hline
\end{tabular}

4 É assim que o Nodo50 se define: "projeto autônomo de contra-informação telemática orientado aos movimentos sociais, uma assembléia independente que proporciona serviços informáticos e comunicativos a pessoas, grupos e organizações de esquerda, um servidor de Internet em que confluem vozes antagonistas e alternativas desde um amplo espectro político; um centro de encontro, difusão e contra-informação para os sem voz, dissidentes, subversivos, utópicos e desencantados... Nada mais e nada menos" (Nodo50, 2005).

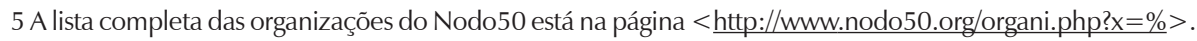


gar suas ações, documentos, dossiês, comunicados, promover suas campanhas, comunicar-se com as representações locais, angariar fundos e aceitar filiações. No caso dessas ONGs mais antigas, falta ainda averiguar qual o tipo de transformação que a Internet ocasionou, de forma concreta, em sua cultura organizacional.

Poderiam ser relacionadas outras redes ou sub-redes menores, intra e trans-organizacionais. Porém essas redes são tão complexas e amplas que necessitariam descrições que vão além do propósito deste artigo, já que envolvem até conexões e contatos individuais de seus membros.

Tais exemplos atestam o surgimento de novas de formas de organização e articulação de indivíduos e coletivos em rede, impossíveis de ocorrer, com tal forma e alcance, há alguns anos atrás. A matéria-prima básica dessa nova forma de organização é a informação gerada e eficazmente distribuída. Este poder resulta da ampliação da capacidade de produzir, reproduzir, compartilhar, expressar e difundir fatos, idéias, valores, visões de mundo e experiências individuais e coletivas em torno de interesses, identidades e crenças - e em um espaço muito curto de tempo.

A possibilidade de comunicação rápida, barata e de grande alcance faz atualmente da Internet o principal instrumento de articulação e comunicação das organizações da sociedade civil, movimentos sociais e grupos de cidadãos. A rede se converteu em um espaço público fundamental para o fortalecimento das demandas dos atores sociais para ampliar o alcance de suas ações e desenvolver estratégias de luta mais eficazes. Agrupando dezenas ou até centenas de organizações de diferentes portes e universos culturais, lingüísticos e identitários ${ }^{3}$ diversos, com base na infra-estrutura da rede mundial, elas conseguem agregar eficiente e eficazmente o descon-

3 Scherer-Warren destaca dois aspectos especialmente relevantes das manifestações simbólicas através das comunidades virtuais: a resistência contra a dominação e a produção de novas identidades (Scherer-Warren, 2002). 
tentamento, para gerar amplas e complexas sinergias em ações globais. Em suma, a rede é um espaço público que possibilita novos caminhos para interação política, social e econômica. Principalmente pelo fato de que nela qualquer cidadão pode assumir, ao mesmo tempo, uma variedade enorme de papéis - como cidadão, militante, editor, distribuidor, consumidor, etc. superando as barreiras geográficas e, até certo ponto, as limitações econômicas (Machado, 2003). Este compartilhamento de valores ocorre com mediações cada vez menores e sem interferência direta de governos e corporações.

Para Keck \& Sikkink, tais articulações são resultados de uma busca mais eficiente para a formação de "um bloco de canais" através de alianças entre grupos locais conectados a uma a rede internacional e seus governos. O compartilhamento da informação teria um papel-chave para a construção de estruturas compartilhadas de significado como parte de sua atividade política (1998: 17). A fonte de sua ação coletiva se baseia na crença das liberdades das teorias liberais e na consciência individual nas quais "o indivíduo pode fazer a diferença" (id., ib.: 2).

Tais redes ${ }^{4}$ exercem uma crescente influência simbólica na responsabilidade política (accountability). É isso que apontam Smith, Pagnucco \&

4 Alguns autores lembram aqui que há uma diferença entre as redes sociais e as redes estruturais. Para Tarrow (1998), os movimentos sociais transnacionais formam "redes conectadas de desafiadores organizados através das fronteiras nacionais" que "sustentam conflitos com oponentes nacionais ou internacionais". Essas redes são sociais quando se compartilham visões de mundo ou se desenvolvem relações organizacionais ou informais entre elas (1998: 184). Para Tarrow, os movimentos sociais transnacionais estão imersos em densas redes sociais onde a "interação diária é essencial para a expansão da ação coletiva". Redes de apoio mútuo, onde predominam formas de organização com, por exemplo, o objetivo de difusão de protesto, mudança política e redes de apoio mútuo (advocacy), seriam redes no sentido de estruturas conectadas, não redes sociais (Tarrow, id.). Rede estrutural é a configuração de relações entre redes locais e outras redes e fatores, aplicando recursos sociais e outros recursos, assim como as relações entre outros recursos e os fatores do recurso focado. (Black \& Boal, 1994). Há uma extensa literatura sobre redes sociais. Em geral, redes sociais entendidas como relações entre atores sociais, assim como modelos de relacionamento entre atores em seus diferentes níveis de análise, como indivíduo ou grupo. 
Chatfield. Para esses autores, isto se daria "por meio do fortalecimento da informação e contra-informação política, do alinhamento de estratégias de atuação, do compartilhamento de metas e outros tipos de apoio recíproco". Dessa forma, tais organizações "conseguem ligar o local, o nacional com o global, assim como as arenas políticas inter- e trans-governamentais, criando assim uma nova estrutura de política global que desagrega o Estado e a política local na intersecção dos níveis nacional e internacional" (Smith, Pagnucco \& Chatfield,1997). A necessidade do compartilhamento de um conjunto de valores em algum nível é outra característica de tais redes, que podem unir, como destaca Escobar (Escobar, 2000) ONGs, fundações, igrejas, grupos de consumidores, movimentos sociais locais e alguns atoresEstado em torno de uma mesma causa.

A forma de organização em redes permite, a partir de apenas alguns pontos nodais, integrar ou conectar redes imensas e diversas. Essas grandes redes de movimentos que se têm articulado pela web nos últimos tempos representam, de alguma forma, o futuro dos movimentos sociais e da ação coletiva? A complexidade de tais conexões não foi ainda suficientemente estudada, mas, provavelmente, tais características representariam um marco de mudança de atuação dos movimentos sociais. Não há como negar que nos defrontamos com tendências muito fortes de transformação, principalmente no que se refere às formas de organização e atuação dos movimentos sociais. Tais redes, assim como outras formas de organizações conhecidas, são caracterizadas pelo voluntariado, reciprocidade e modelos horizontais de comunicação e intercâmbio. Nisso não há novidade. O que chama a atenção é que tais elementos foram enormemente potencializados com o uso das tecnologias de informação.

3.2 Novas tecnologias de informação e comunicação e a radicalização de movimentos sociais

Nos últimos anos, um outro aspecto que tem chamado a atenção dos cientistas sociais e políticos é o notável aumento do ativismo político atra- 
vés do hackerismo. O hackerismo inclui formas muito diferentes de atuação, que envolvem problemas tão diversos como de difícil interpretação no que se refere aos enfoques tradicionais sobre o direito internacional, a democracia, as liberdades civis, as formas de organização política e identidades e valores sociais.

Uma das mais conhecidas empresas de segurança na Internet constatou que boa parte dos ataques registrados a sites de corporações e governos tem, como fundo, motivações políticas e ideológicas. A Mi2G coletou informação sobre mais de 100 mil ocorrências provocadas por cerca de 6 mil grupos de hackers. Um ataque digital ocorre quando um grupo hacker obtém acesso não-autorizado a um sistema on-line e realiza modificações em algum de seus componentes - portanto, conceitualmente não se trata apenas de invasão. Tais ataques digitais aumentam em períodos de conflito político. Um exemplo, é o da guerra do Iraque. Por ocasião dela, houve um recorde de ataques digitais com sucesso perpetrados por grupos pró-islâmicos e pacifistas ocidentais - cerca de 30 mil casos, em maio de 2003 (Mi2G, 2003). Ondas de ataque semelhantes ocorreram, por razão da guerra da lugoslávia, durante os períodos de tensão entre China e Taiwan, entre Israel e Palestina - a "Intifada Digital" - e também quando um avião espião estadunidense foi flagrado e retido na China, em abril de 2001 (Machado, 2003).

A relevância destes dados aumenta quando se observa que a maior parte das ocorrências analisadas pela Mi2G tem relação com alguma forma de ativismo classificadas principalmente em quatro categorias, "tensão política", "protesto e guerra digital", "protesto anti-globalização ou anti-capitalismo" e "ativismo ecológico e em prol dos direitos humanos". Considerando que muitas das ações identificadas como "hackerismo recreacional" têm como objetivos causar perdas e danos a grades corporações, não se pode excluir a existência ou a combinação com motivações de fundo ideológico ou político, na razão de sua ocorrência. 
Os prejuízos com atividades de hackers em 2004, incluindo os programas maliciosos ("malwares") ultrapassaram a soma de 500 bilhões de dólares (Mi2G, 2005). Para efeito de comparação, em 1996, os danos foram de "apenas" 800 e 900 milhões de dólares (Mi2G, 2003). Alguns dos fatores que contribuem para o aumento contínuo dos ataques são: a constante inovação tecnológica, a crescente interconexão global, o incremento da digitalização e da comunicação nas práticas e trâmites empresariais e governamentais, o baixo custo e o baixo risco em relação ao dano causado e a dificuldade para se chegar ao atacante, são alguns dos fatores que contribuem para o aumento contínuo dos ataques. Atrevemo-nos a afirmar que a constante informatização, aumento e integração dos bancos de dados, conjugada com a melhoria nas formas de conexão remota, haverá cenários para verdadeiras guerras digitais, com o hackerismo e o crackerismo e suas variantes crescendo enormemente.

Qual é a fronteira entre hackerismo, ativismo político e movimentos sociais? O hackerismo motivado política e ideologicamente se tornou tão freqüente que ganhou a denominação de hacktivismo. Por ser considerado um crime, seus executores preferem não se identificar. Ainda que seja difícil afirmar quem realmente o pratica, muitos coletivos radicais o utilizam. É sabido que redes de organizações como a "No Border" ou movimentos ou coletivos sociais integrantes da Nodo50, Oxfam, PeaceNET e EcoNET já o utilizaram. ${ }^{5}$ Atualmente centenas de membros de algumas dessas entidades respondem a processos em seus respectivos países ou são

5 Uma das formas mais utilizadas de ataque, até por sua simplicidade, é o denial of service distribuído. Trata-se do envio de milhares de requisições a um servidor ao mesmo tempo até leválo "abaixo". Um grupo de hacktivistas que o utiliza é o Electronic Disturbance Theater, que até desenvolveu para isso o software Floodnet. Em 2002, esse mesmo grupo "derrubou" o servidor do site do Fórum Econômico Mundial, durante sua realização em Nova York, prejudicando organizadores, participantes e jornalistas que dependiam das informações, boletins e documentos difundidos pelo servidor. 
acusados em outros (ver o caso da No Border, em Machado: 2003). Desde suas origens, o hackerismo teve ligação com a contracultura, conforme já descreveu Castells (2003: 122-4). É conhecida sua associação com outras formas de militância, com movimentos alternativos e a juventude de esquerda.

Apesar dos riscos da ação, não há nenhuma evidência que práticas tão eficazes quanto "acessíveis" possam ser abandonadas. Pelo contrário, em um contexto caracterizado por um capitalismo de grandes corporações, profundas desigualdades e graves injustiças, a sociedade da informação, com tantos sistemas complexos conectados, oferece um horizonte tão amplo quanto atrativo para as criativas intervenções do hacktivismo.

O maior problema é a dificuldade de lidar com o tema desde o ponto de vista legal e político. Isso porque o que ocorre no ciberespaço é, em tese, assunto de todos e de nenhum país ao mesmo tempo. Para a Justiça da maioria dos países, ainda não está definida qual é fronteira entre este ativismo virtual e uma ação criminal. Os marcos tradicionais dos Estados-nacionais são insuficientes para oferecer garantias e delinear limites para as mobilizações e práticas políticas no ciberespaço. Ademais, a maior parte dos países não tem legislação específica para tratar do assunto. O tema acaba ficando à mercê da interpretação de juízes locais, o que freqüentemente tem sido a causa de grandes mal-entendidos (ver Schiller, 1997; Machado, 2002).

3.3 Características dos Movimentos Sociais face às novas Tecnologias de Informação e Comunicação

Depois de apresentar uma breve descrição das mudanças nas formas de atuação dos movimentos sociais, cabe sumarizar as características dos movimentos sociais que atuam por meio das redes telemáticas. Nos tópicos a seguir, combino minha interpretação com alguns dos recentes enfoques de Giddens, Castells, Melucci e Hall sobre movimentos sociais e identidade.

1) Proliferação e ramificação dos coletivos sociais. A rapidez e alcance das novas tecnologias de informação permitem uma proliferação das orga- 
nizações civis e dos coletivos sociais, assim como uma integração eficiente e estratégica entre os mesmos; baseada principalmente no idealismo e voluntarismo de seus membros, incentivados pela relação custo-benefício bastante favorável. Surgem novas formas de alianças e sinergias de alcance global. Com isso, aumentaram enormemente as formas de mobilização, participação, interação, acesso à informação, bem como a provisão de recursos, as afiliações individuais e as ramificações entre os movimentos sociais.

2) Horizontalidade e flexibilidade das redes. As organizações tendem a ser cada vez mais horizontais, menos hierarquizadas, mais flexíveis, com múltiplos nós, conectadas a numerosas microredes ${ }^{6}$ ou células que podem ser rapidamente ativadas. Conforme Castells (2001: 426), os novos movimentos sociais se caracterizam cada vez mais por "formas de organização e intervenção descentralizada e integrada em rede".

3) Tendência coalizacional. Atuam crescentemente em forma de rede coalizacionais (Diani, 2003, Escobar, 2000), de alcance mundial, em torno de interesses comuns e com base na infra-estrutura de comunicação propiciada pela Internet.

4) Existência dinâmica ou segundo objetivos ou fatos. Têm grande dinamismo, podem formar-se, alcançar certos objetivos, causar impacto e repercussão, expandir-se por razão de um fato político e da mesma forma, podem rapidamente se desmanchar ou desaparecer, conforme a situação (passado o fato, com o objetivo alcançado ou o fracasso).

5) Minimalismo organizacional-material. A sede física se tornou irrelevante: fax, telefone ou endereço postal passam a ser itens secundários. A possibilidade de operação a um custo muito baixo incentiva a associação individual, a emergência de novos movimentos sociais e as associações dos movimentos entre si. 
6) Universalismo e particularismo das causas. Ainda que possa parecer contraditório, os ideais podem ser universalistas e particularistas. Podem atender a uma ou a um conjunto de aspirações de coletivos sociais bastante pequenos e específicos (e até mesmo, geograficamente separados). No entanto, ainda que ligadas a uma causa ou tema específico, as lutas podem orientar-se cada vez mais com relação a um quadro mais amplo de lutas, que diz respeito a princípios de aceitação universal, como desenvolvimento sustentável, direitos humanos, direito à autodeterminação dos povos, combate ao racismo e formas de discriminação, democracia, liberdade de expressão, etc.

7) Grande poder de articulação e eficiência. Permitem a organização de protestos simultâneos em diferentes cidades e países, assim como a articulação local de vários grupos de manifestantes dispersos. Ao contrário do que se possa crer, a convergência de interesses não se dá somente no plano "virtual". Ela se materializa também por ações concretas. É o caso, por exemplo, das ações do 'Move On', 'No Border', 'Oxfam', 'Confédération Paysanne', ATACC, grupos Okupa, entre outros. Sua geometria pode ser variável, concentrando e ativando seus nós e combinando estratégias variáveis conforme a necessidade.

8) Estratégias deslocalizadas de ideologias compartilhadas. As estratégias no espaço dos fluxos são deslocalizadas, buscam ligar identidades, objetivos, ideologias e visões de mundo compartilhadas. Identidade e solidariedade passam a desempenhar papéis fundamentais para a formação de tais redes.

Essa característica se associa ao que Castells chama de identidades de resistência. Segundo ele, esta se daria em "sociedades civis em processo de desintegração" em que a identidade seria um elemento de "resistência comunal" (2001: 25).

9) Multiplicidade de identidades / circulação de militantes. Permite a circulação dos militantes nas redes. Um mesmo ativista pode estar enreda- 
do com outras causas, com outros atores coletivos; pode militar em vários movimentos e, mesmo transmitir sua reivindicações nas diferentes redes de que participa (através de suas conexões identitárias). Como a união de seus membros pode ser apenas específica ou pontual, não é incomum a participação de um mesmo indivíduo em diferentes movimentos sociais, compartilhando um interesse com pessoas que, em outras dimensões da vida social, têm aspirações, valores e crenças bem diferentes.

Para Giddens, a auto-identidade é uma característica fundamental do que chama "modernidade tardia". Segundo ele, em um cenário de crescente interconexão entre a intencionalidade e a "extencionalidade" - capacidade de interação com elementos cada vez mais globais - do indivíduo, a este é possível negociar uma série de estilos e opções de vida, construindo sua identidade em termos de sua interação dialética com o global.

Esta circulação de militantes nas redes através das múltiplas identidades pode ser associada com uma das características da contemporaneidade, segundo Hall: a fragmentação das identidades - antes unificadas e estáveis. Para esse autor, com a "multiplicação" dos sistemas de representação cultural, o indivíduo passa a ser confrontado por uma multiplicidade de identidades possíveis "com cada uma das quais pode se identificar ao menos temporariamente" (Hall, 2004: 13). Castells, ao falar da construção social da identidade, refere-se a "identidade de projetos" quando "os atores sociais, utilizando-se de qualquer tipo de material cultural ao seu alcance constroem uma nova identidade" (Castells, 2001: 24). Para ele, a "identidade de projetos" está relacionada à construção de projetos de vida por prolongamentos da identidade e experiências do indivíduo, os quais dão espaço ao surgimento de novos sujeitos (id., ib.: 26).

10) Identidade difusa dos sujeitos sociais. O anonimato e a multiplicidade de identidades potencializam as formas de ativismo. Por esta mesma razão, é cada vez mais difícil tratar de questões identitárias dos movimentos sociais. 
Os interesses dos indivíduos que os ligam em redes são cada vez mais cruzados, diversos e freqüentemente tênues. Luta-se cada vez mais em torno de códigos culturais, valores e interesses diversos. Essa luta se dá, cada vez menos, a partir dos indivíduos e mais sobre a construção de sujeitos sociais. Esta complexidade característica dos movimentos sociais contemporâneos foi percebida por Melucci. Para ele, eles têm estruturas cada vez mais difíceis de serem especificadas como ator coletivo, possuindo "formatos cada vez mais indistintos e densidades variáveis" (Melucci, 1996: 114).

\section{Conclusão}

No decorrer deste texto, busquei demonstrar como as tecnologias de informação, com especial atenção à Internet, proporcionaram novos horizontes para o ativismo político e o engajamento nas lutas sociais. A "apropriação" de espaços na rede mundial pelos movimentos sociais tem contribuído para o fortalecimento das demandas sociais, ao oferecer certos tipos de organização, formas de articular ações e de se fazer política, que não existiam antes.

Manifestações com apoio amplo e diversificado e articulações de grande escala como as ocorridas por ocasião das cúpulas e reuniões do G7, OMC, FMI, Banco Mundial, Fórum Econômico Mundial e da Guerra do Iraque não poderiam ter sido realizadas há alguns anos atrás - ou, pelo menos, sem uma dificuldade muito maior - , pois dependeram do uso das modernas tecnologias de informação e comunicação. Observou-se nesses casos que, independentemente dos meios tradicionais e de certos mecanismos de controle social e a partir de centenas de nós formados por coletivos e ativistas de todo tipo, os movimentos sociais conseguiram que um enorme fluxo de informações circulasse, resultando em uma eficiente articulação de meios, recursos e estratégias para grandes mobilizações. 
Tal forma de organização e tais instrumentos têm permitido não apenas a constituição, mas também a existência de novos entes políticos. Conforme já descrito, vários atores sociais surgem e se formam apoiados em redes e sub-redes menores, espécies de células "dormentes", que podem ser ativadas a qualquer momento, segundo uma lógica relacionada a elementos identitários, valores e ideologias. Trata-se de um jogo em que as múltiplas identidades sociais, interesses e idéias se articulam e se combinam com grande dinamismo em torno de objetivos e fins específicos e determinados. O que chamamos de "forças dormentes", nada mais são do que pessoas conectadas que, ainda que individualmente pouco possam fazer além de se indignar ante uma injustiça, quando organizadas em uma rede, sentem-se encorajadas para participar de ações e desencadeá-las. Os movimentos sociais articulados em rede têm o poder de agregar essas "identidades individuais", freqüentemente anônimas e dispersas, ativando os elementos identitários de solidariedade.

Para poder fazer frente aos interesses de grandes atores, os movimentos sociais têm como principal recurso - e, por vezes, o único - a informação. Estrategicamente difundida e aliada a formas de articulações tradicionais como manifestações, protestos, campanhas mundiais -, a informação e o conhecimento podem eficazmente desencadear processos de mudança social. A informação é apenas uma matéria bruta que pode ser transformada em ideologia. Por isso, os movimentos sociais se orientam cada vez mais em torno dos meios de comunicação - cujo poder de persuasão pode ser, por vezes, muito mais poderoso do que, por exemplo, o uso da força - para difundir e compartilhar valores, visões de mundo e experiências.

A partir de tal interpretação, vê-se uma intersecção bastante favorável para que ocorra essa conexão em redes entre os movimentos sociais. Neste sentido, vale lembrar o conceito de "repertórios da ação coletiva", de Tilly (1978). Aprendidos pela tradição política, pela participação e por sua 
circulação nas mídias, esses "repertórios" são responsáveis por um maior alcance e mais possibilidades de ação coletiva. Sob este enfoque, inovação, difusão e incorporação de certas formas de ação coletiva dependem da rotina da população, suas experiências, organização e modelos de sociedade a que são expostos. Com o aumento do uso das tecnologias de informação e comunicação, tais repertórios são cada vez maiores. Experiências, modelos sociais, valores e signos são cada vez mais difundidos, confrontados e compartilhados, criando um amplo horizonte de transformação simbólica e social.

Consolida-se também a tendência de que a maior parte dos movimentos sociais através da rede se oriente por valores universais como direitos humanos, minorias, liberdade de expressão, preservação ambiental e outros, reivindicando as garantias das leis do moderno Estado democrático - ainda que seja para transgredi-lo. Tais valores, pelo fato de serem cada vez "mais universais", criam fortes identificações, que facilitam a integração no plano axiológico e simbólico de movimentos sociais. A partir de tal interpretação, vê-se uma intersecção bastante favorável para que ocorra essa conexão em redes entre os movimentos sociais.

O que tece tais redes de coletivos sociais são relações, conflitos e processos políticos e sociais que ocorrem na sociedade, cujas causas e conseqüências se entrelaçam no cotidiano cada vez mais compartilhado dos atores. Assim como outros aspectos das relações sociais mediadas por computadores, os conflitos e processos de mudança reverberam e se difundem nas redes telemáticas até alcançar o cotidiano das pessoas e "conquistar" suas mentes. Os agenciamentos para a mudança social ocorrem sob novos contornos, nos quais interação, intenção, conexão, identidade e ação desempenham papéis cada vez mais fundamentais, fazendo com que os atores sociais tenham uma extensão e influência cada vez maior, criando um ambiente propício à emergência de novas formas de ação coletiva.

Deve-se chamar a atenção de que tais mudanças nas estruturas e formas de atuação dos movimentos sociais ainda estão em uma etapa inici- 
al. Há ainda um grande horizonte de transformações pela frente, considerando a dificuldade de conexão em muitos países do mundo, o analfabetismo digital ou as dificuldades e limites decorrentes da alfabetização digital tardia dos estratos etários superiores, o predomínio de setores da classe média em tais organizações e, sobretudo, porque se trata de transformações operadas em sua maioria por uma geração que ainda há de assumir posições mais importantes na sociedade. Tais transformações, portanto, dependem ainda da assimilação de novas práticas culturais, ainda presentes em setores minoritários da sociedade global e da emergência de uma nova geração majoritariamente habituada ao uso de tais ferramentas.

\section{Referências}

ALEXANDER, Jeffrey C. Ação Coletiva, Cultura e Sociedade Civil - Secularização, atualização, inversão, revisão e deslocamento do modelo clássico dos movimentos sociais. Rev. Brasileira de Ciências Sociais, n. 37, vol. 13, 1998 < http:// www.scielo.br/scielo. php?script=sci _arttext \&pid=S010269 0919980002000 $01 \& \operatorname{lng}=$ en\&nrm =iso\&tlng $=$ pt $>$. (Acesso em 12 ago. 2005).

APC. Nuestros Miembros. < http://www.apc.org/espanol/about/members/ index.shtml $>$. (Acesso em 12 ago. 2005).

BLACK, J.A. \& BOAL, K. B. Strategic resources: Traits, configurations, and paths to sustainable competitive advantage. Strategic Management Journal [SMJ], 15, 131 - 148.

BLUMER, H. Collective behaviour In: PARK, R.E. (ed.) An outline of the principles of sociology. N. York: Barnes and Noble,1939.

. Collective behaviour In: J. B. Glitter, Review of Sociology: Analysis of a Decade, pp. 127-158. N. York: Wiley, 1957.

CASTELLS, Manuel. Galaxia da Internet. São Paulo: Jorge Zahar, 2003.

. A Era da Informação: Economia, Sociedade e Cultura. Vol. II: O Poder da Identidade. São Paulo: Paz e Terra, 2001. 
DIANI, Mario. 'Leaders' Or Brokers? Positions and Influence in Social Movement Networks. In DIANI, M. \& McADAM, D. (Eds.) Social Movements and Networks Relational Approaches to Collective Action. Oxford: Oxford Univ. Press, 2003.

ESCOBAR, Arturo. Notes on Networks and Anti-Globalization Social Movements. Paper, 2000 Annual American Anthropological Association Meeting, November 2000, University of North Carolina, Chapel Hill. <http://www.unc.edu/depts/ anthro/faculty/fac_pages/escobarpapers/ notesnetwork.pdf > (Acesso em 16 ago. 2005).

FROMM, Eric. Escape from Freedom. N. York: Rinehart, 1941

GEIGER, T. Die Masse und Ihre Aktion. Stuttgart: Enke.

GIDDENS, Anthony. Modernidade e Identidade. São Paulo: Jorge Zahar, 1997. . As Conseqüências da Modernidade. São Paulo: Unesp, 1991.

GOFFMAN, E. The Presentation of Self in Everyday Life. N. York: Doubleday Anchor, 1959.

. Interaction Ritual. Garden City: Doubleday, 1967.

GOHN, Maria da Glória. Teoria dos Movimentos Sociais. São Paulo: Loyola, 2004.

GTW. About < http://www.citizen.org/trade/about/> (Acesso em 16 ago. 2005).

HALL, Stuart. A Identidade Cultural na Pós-modernidade. Rio de Janeiro: DP\&A, 2004.

HEBERLE, R. Social Movements. An Introduction to Political Sociology. N. York: Appleton-Century-Crofts, 1951.

HELD, David. La Democracia y El Orden Global - Del Estado Moderno al Gobierno Cosmopolita. Barcelona: Paidós, 1997.

HOFFER, E. The True Believer: Thoughts on the Nature of Mass Movements. N. York, Mentor, 1951.

IGC. About IGC. <http://www.igc.org/html/aboutigc.html> (Acesso em 09 ago. 2005). 
KECK, M.; SIKKINK, K. Activists Beyond Borders. Advocacy Networks in International Politics. Ithaca: Cornell University Press, 1998.

KOBRIN, Stephen. Territoriality and the Governance of Cyberspace, Journal of International Business Studies, Winter, v32 i4, p. 687(18), 2001.

KORNHAUSER, W. The Politics of Mass Society. Glencoe: Freepress, 1959.

. Mass Society. In: International Encyclopedia of the Social Sciences, vol. 10, pp. 58-64, N. York: Macmillan, 1968.

LE BON, Gustav. The Crowd: A study of the popular mind. 2nd ed. Dunwoody, Georgia: Norman S. Berg < http://www.propaganda101.com/OnlineBooks/LeBon/ LeBon_1895/TheCrowd/LeBon_1895_00> [1895] (Acesso em 16 set. 2005).

LIPSET, S. M.. Agrarian Socialism. Berkeley: Univ. Califórnia Press, 1950.

MACHADO, Jorge. Internet, Ativismo Político e Controles Governamentais, paper apresentado no XI Congresso da Sociedade Brasileira de Sociologia, Campinas, Brasil, 1 a 5 de setembro de 2003.

. O Ciberespaço como Arquitetura da Liberdade - Tentativas de Territorialização e Controle da Rede. In ALVES, G.; MARTINEZ, V. (Orgs.) Dialética do Ciberespaço, Bauru: Práxis. Online: <http://www.forum-global.de/bm/articles/ ciberespaco_territorializacao_jorgemachado.htm $>$.

MELUCCI, Alberto. Acción Colectiva, Vida Cotidiana y Democracia. México D.F: El Colegio, 2003.

Challenging Codes - Collective Action in the Information Age. Cambridge: Cambridge Univ. Press, 1996.

Mi2G. 2004: Digital risk global economic damage tops USD 500 billion, Mi2G Report 16 February, <http://www.mi2g.com/cgi/mi2g frameset. php?pageid =http $\% 3 \mathrm{~A} / /$ www.mi2g.com/cgi/mi2g/press/160205.php $>$ (Acesso em 15 ago. 2005).

. Monthly World Record for Overt Digital Attacks Broken - Politically Motivated Attacks Major Contributing Force, MiG2 Report 21 may 2003, < http:// www.mi2g.com/cgi/mi2g/frameset.php?pageid=http\%3A//www.mi2g.com/cgi/ mi2g/press/210503.php> (Acesso em 10 ago. 2005). 
NODO50. FAQ. < http://www.nodo50.org/faq.htm> (Acesso em 09 ago. 2005).

OLIVER, Pamela; MYERS, Daniel J. Networks, Diffusion, and Cycles of Collective Action. In DIANI, M.; McADAM, D. (Eds.) Social Movements and Networks Relational Approaches to Collective Action. Oxford: Oxford Univ. Press, 2003.

OXFAM. About <http://www.oxfam.org/esp/about.htm> (Acesso em 10 ago. 2005).

PARSONS, Talcott. The Structure of Social Action. Nova lorque, McGraw-Hill, 1937.

PASQUINO, Gianfranco. Movimentos Sociais. In BOBBIO, N; PASQUINO, G; MATTEUCCI (Eds.) Dicionário de Política. Vol. 2, pp. 787-92. Brasília: Ed. UnB, 1994.

SCHILLER, T.; WILSKE, S. International Jurisdiction in Cyberspace: Wich States May Regulate the Internet. Federal Communications Law Journal, vol. 50, number 1 dezember, 1997. < http://www.law.indiana.edu/fclj/pubs/v50/no1/wilske.html>. (Acesso em 09 ago. 2005).

SELZNICK, P. The Organizational Weapons. N. York: McGraw-Hill, 1952

SMELSER, N. Theory of Collective Behavior. London: Routledge \& Kegan, 1962.

SMITH, J.; CHATFIELD, C; \& PAGNUCCO, R. Social Movements and World Politics. A Theoretical Framework. In SMITH, J.; CHATFIELD, C; \& PAGNUCCO, R (Eds.), Transnational Social Movements and Global Politics. Syracuse: Syracuse University Press, 1997.

SCHERER-WARREN, Ilse. Movimentos sociais e educação na era da informação. Revista de Educação Pública, v.19. Mato Grosso: Ed. UFMT, p. 139-145, 2002.

TARDE, Gabriel. Les lois de l'imitation. 2a . Les classiques des sciences sociales. Québec: I'Université du Québec à Chicoutimi. (2004) [1895] < http:// www.uqac.uquebec.ca/zone30/Classiques_des_sciences_sociales/index.html > (consulta em 14/07/2005).

TARROW, Sidney. 1994. Power In Movement. Social Movements, Collective Action And Politics (2nd Edition). New York/Cambridge: Cambridge University Press.

THIRD WORLD NETWORK. Introduction < http://www.twnside.org.sg/ twnintro.htm> (Acesso em 09 ago. 2005). 
Sociologias, Porto Alegre, ano 9, no 18, jul./dez. 2007, p. 248-285

THURNWALD, R. Partei und Klasse im Lebensprozess. Leipzig: Der Gesellschaft, 1926.

TILLY, Charles From Mobilization to Revolution. Reading, Mass., Addison-Wesley, 1978.

TOURAINE, A. La producción de la sociedad. México, IISUNAM, 1995. 


\section{Resumo}

Neste trabalho, busco identificar as principais características das novas formas de organização dos movimentos sociais, com base no uso das novas tecnologias de informação e comunicação. A partir da descrição de alguns casos, é mostrado como os coletivos sociais atribuem à Internet um papel central em suas formas de articulação, desenvolvendo com êxito novas formas de organização, com compartilhamento de metas, alinhamento de estratégias e formação de coalizões e alianças de alcance global. Tal fenômeno abre um amplo horizonte de transformações e mudanças sociais, que apontam para o surgimento de novas dinâmicas de ação coletiva com base em complexas redes identitárias, orientadas por valores "universais". É sobre tais tendências que enfoco a análise neste paper.

Palavras-chave: movimentos sociais, ativismo político, redes, ação coletiva, tecnologias de informação.

Recebido: 30/08/05

Aceite final: 23/05/06 